\title{
Hubungan Kewenangan Pusat dan Daerah dalam Penyelenggaraan Otonomi Daerah Di Bidang Pendidikan Berdasarkan Undang-Undang Nomor 23 Tahun 2014 Tentang Pemerintahan Daerah
}

\author{
Danetta Leoni Andrea ${ }^{凶}$ \\ Fakultas Hukum Universitas Padjadjaran \\ E-mail: danettaleonia@gmail.com
}

\begin{abstract}
The existence of the autonomous region gave birth to the relationship of authority between the Central Government with the regions. In this case, the relationship between the central authorities and the region will be discussed by the author is more specialize into the relationship of the authority in the field of education. Given that national education systems have an important role in feeding the nation of Indonesia considering also that at this time has entered the era of the globaisasi, then the necessary higher education human resources capable of generating Indonesia quality in order to compete internationally. The existence of a connection between the central area can be seen from the governmental Affairs Division in the field of education which includes the management of education, curriculum, accreditation, educators and educational personnel, licensing education, as well as in terms of discussion and literature. As for the research methods used by the author is the juridical normative research, where the source of the data used is to use insturumen-legal instruments related to local governance and National education systems as well as by using the results of the study of librarianship.
\end{abstract}

Keywords: Education, The Relationship Of Authority, Regional Autonomy, Central Government, Regional Government.

\begin{abstract}
Abstrak
Adanya otonomi daerah menimbulkan hubungan kewenangan antara pemerintahan pusat dengan daerah. Dalam hal ini, hubungan kewenangan antara pusat dan daerah yang akan dibahas oleh penulis adalah lebih mengkhususkan kedalam hubungan kewenangan di bidang pendidikan. Mengingat bahwa sistem pendidikan nasional memiliki peran yang penting dalam mencerdaskan bangsa Indonesia. Selain itu, sebubungan dengan era globaisasi maka diperlukan pendidikan yang mampu menghasilkan Sumber Daya Manusia Indonesia yang berkualitas agar dapat bersaing di dunia Internasional. Adanya hubungan antara pusat dengan daerah dapat terlihat dari pembagian urusan pemerintahan dalam bidang pendidikan yang meliputi manajemen pendidikan, kurikulum, akreditasi, pendidik dan tenaga kependidikan, perizinan pendidikan, serta dalam hal bahasa dan sastra. Adapun metode penelitian yang digunakan oleh penulis adalah penelitian yuridis normatif, dimana sumber data yang digunakan adalah dengan menggunakan insturumen-instrumen hukum yang berkaitan dengan Pemerintahan Daerah dan Sistem Pendidikan Nasional serta dengan menggunakan hasil kajian dari bahan-bahan kepustakaan.
\end{abstract}

Kata Kunci: Bidang Pendidikan, Hubungan Kewenangan, Otonomi Daerah, Pemerintahan Pusat, Pemerintahan Daerah.

\section{Pendahuluan}

Sebagai sebuah negara kesatuan yang berbentuk republik, Indonesia membentuk Pemerintahan Daerah dalam rangka meningkatkan akuntabilitas, efektifitas, serta efisiensi didalam penyelenggaraan serta pelaksanaan pemerintahan di Indonesia di seluruh wilayah Indonesia. Keberadaan Pemerintahan Daerah yang dibentuk tersebut memiliki peran dalam hal menyelenggarakan serta melaksanakan urusan-urusan pemerintahan di daerah sesuai dengan 
Kosmik Hukum Vol. 20 No. 2 (2020): 73-80

E-ISSN: 2655-9242 | P-ISSN: 1411-9781

DOI: $10.30595 /$ kosmikhukum.v20i2.7156

pembagian urusan antara pusat dengan daerah yang terdapat didalam Undang-Undang. Berkenaan dengan hal tersebut, pembagian daerah yang ada di Indonesia meliputi wilayah

provinsi, kabupaten dan kota, dimana masing-masing wilayah tersebut memiliki Pemerintahan Daerahnya sendiri yang diatur ketentuan-ketentuannya didalam UndangUndang. ${ }^{1}$ Prof. Dr. Jimly Asshiddiqie, mengatakan bahwa didalam sebuah struktur pemerintahan terdapat tiga wilayah dimana masing-masing wilayah tersebut memiliki otonominya sendiri yang meliputi pemerintah pusat, provinsi, dan kota atau kabupaten. ${ }^{2}$

Pemberian otonomi kepada suatu daerah tersebut pada dasarnya adalah sebuah bentuk nyata dari sistem desentralisasi. Desentralisasi adalah pendistribusian kewenangan dan urusan pemerintahan dalam suatu organisasi negara. ${ }^{3}$ Yang menjadi poin penting dalam desentralisasi adalah adanya pembagian urusan-urusan dari titik pusat ke titik daerah ${ }^{4}$ dan juga berpindahnya tanggung jawab dalam membuat keputusan tertentu. ${ }^{5}$ Desentralisasi tersebut tentunya memiliki manfaat, yang paling terlihat yaitu adanya pelaksanaan urusan-urusan pemerintahan termasuk urusan administrasi yang menjadi lebih produktif dan efektif. ${ }^{6}$ Desentralisasi dalam sistem pemerintahan di Indonesia mengacu kepada pembentukan daerah otonom yang akan menjadi tempat kewenangan yang diserahkan oleh pusat akan dilaksanakan.

Mengingat bahwa Indonesia adalah negara Kesatuan, maka Otonomi daerah dapat dikatakan sebagai sebuah instrument untuk memelihara negara kesatuan berdasarkan hukum untuk mewujudkan pemerataan kesejahteraan, dan keadilan di berbagai bidang di seluruh daerah di Indonesia. Selain itu pula, dengan otonomi daerah, pelaksanaan demokrasi dapat diperluas dimana setiap wilayah yang berada di Indonesia dapat secara mandiri mengatur dan mengurus rumah tangganya. Hal tersebut sangat penting untuk menunjukkan bahwa kehadiran daerah tetap penting walaupun terdapat tuntutan kesatuan negara Indonesia. Serta dengan adanya otonomi, kesejahteraan umum dapat diwujudkan secara lebih efektif dan efisien pada setiap daerah, mengingat bahwa dalam mewujudkan kesejahteraan umum tentu akan dihadapkan dengan keadaan-keadaan yang berbeda dari setiap daerah, dan mengikuti dinamika dari kebutuhan masyarakat daerah setempat. ${ }^{7}$

Dengan ditetapkannya Undang-Undang Nomor 23 Tahun 2014 tentang Pemerintahan Daerah, otonomi daerah di Indonesia memasuki era baru. ${ }^{8}$ UU Pemda 2014 ini merupakan perwujudan dari semangat otonomi daerah di Indonesia. ${ }^{9}$ Otonomi daerah menurut Pasal 1 angka (6) Undang-Undang Nomor 23 tahun 2014 tentang Pemerintahan Daerah (UU Pemda 2014) menekankan adanya demokrasi, dimana mengurus sendiri kepentingan masyarakat setempat adalah hak kewenangan daerah otonom yang kemudian juga dilaksanakan dengan memperhatikan potensi dan kearifan lokal, serta partisipasi masyarakat dalam sistem Negara Kesatuan Republik Indonesia. Hakikat otonomi daerah sesuai dengan UU Pemda 2014 adalah untuk meningkatkan inisiatif daerah local dalam membangun kemandirian daerah.

Undang-Undang Dasar Republik Indonesia Tahun 1945 Pasal 18 ayat (1)

Jimly Asshiddiqie, 2013, Komentar atas Undang-Undang Dasar Negara Republik Indonesia Tahun 1945, Jakarta: Sinar Grafika, hlm. 57.

3 Oentarto Sindung Mawardi, 2004, Menggagas Format Otonomi Daerah Masa Depan, Jakarta: Samitra Media Utama, hlm.1.

4 Lauglo, J, 1999, "Forms of Decentralisation and Their Implications for Education", Comparative Education, Volume 31, Issue. 1, hlm. 5.

5 Edward B. Fiske, 1996, Decentralization of Education: Politics and Consensus, Washington DC: The World Bank, 1996.

6 Terry Rounds Parry, 2008, "Decentralization and Privatization: Education Policy in Chile", Journal of Public Policy, Volume 17, Issue 1.

Bagir Manan, 2001, Menyongsong Fajar Otonomi Daerah, Yogyakarta: PSH FH UII, hlm 3.

8 Septi Nur Wijayanti, 2016, "Hubungan Antara Pusat dan Daerah Dalam Negara Kesatuan Republik Indonesia Berdasarkan Undang-Undang Nomor 23 Tahun 2014", Jurnal Media Hukum, Volume 23, Nomor 2, hlm. 193.

9 Septi Nur Wijayanti, 2016, “Hubungan Antara Pusat dan Daerah Dalam Negara Kesatuan Republik Indonesia Berdasarkan Undang-Undang Nomor 23 Tahun 2014", Jurnal Media Hukum, Volume 23, Nomor 2, hlm. 193. 
Adanya otonomi daerah kemudian melahirkan hubungan antara pemerintahan pusat dengan daerah, yang salah satunya adalah hubungan kewenangan. ${ }^{10}$ Dalam hal ini, hubungan kewenangan antara pusat dan daerah yang akan dibahas oleh penulis adalah lebih mengkhususkan kedalam hubungan kewenangan di bidang pendidikan. Mengingat bahwa sistem pendidikan nasional memiliki peran yang penting dalam mencerdaskan bangsa Indonesia mengingat pula bahwa saat ini telah memasuki era globaisasi, maka diperlukan pendidikan yang mampu menghasilkan Sumber Daya Manusia Indonesia yang berkualitas agar dapat bersaing di dunia Internasional. Sehingga diperlukan adanya pendidikan yang diselenggarakan dan dilaksanakan secara merata di seluruh wilayah Indonesia. Berkaitan dengan hal tersebut, maka diibutuhkan adanya hubungan kewenangan antara pemerintahan pusat dengan pemerintahan daerah yang dalam hal ini adalah dalam Bidang Pendidikan, yang dilakukan melalui adanya pembagian urusan, sehingga kemudian dapat diketahui secara tegas dan jelas bagaimana ruang lingkup kewenangan pusat maupun kewenangan daerah dalam mengelola dan melaksanakan pendidikan baik itu dalam tingkat pendidikan tinggi, menengah, dasar, maupun pendidikan khusus. Berdasarkan latar belakang tersebut, maka penulis kemudian tertarik untuk mengambil judul "Hubungan Kewenangan Pusat dan Daerah dalam Penyelenggaraan Otonomi Daerah di Bidang Pendidikan Berdasarkan Undang-Undang Nomor 23 Tahun 2014 tentang Pemerintahan Daerah".

\section{Metodologi Penelitian}

Metode penelitian yang digunakan dalam penulisan ini adalah penelitian yuridis normatif, dimana mengkaji bagaimana penerapan kaidah-kaidah atau norma-norma dalam hukum positif. Sumber Data yang digunakan adalah dengan menggunakan insturumeninstrumen hukum yang berkaitan dengan Pemerintahan Daerah dan Sisten Pendidikan Nasional serta dengan menggunakan hasil kajian dari bahan-bahan kepustakaan.

\section{Hasil dan Pembahasan}

\section{Hubungan Pusat dan Daerah Berdasarkan Undang-Undang Nomor 23 Tahun 2014 tentang Pemerintahan Daerah}

Menurut Prof. Dr. Bagir Manan, faktor yang menentukan hubungan pusat dan derah dalam sebuah otonomi yaitu adanya hubungan kewenangan, hubungan keuangan, hubungan yang timbul dari susunan organisasi pemerintahan di daerah, dan hubungan pengawasan. ${ }^{11}$ Pertama, hubungan kewenangan antara pusat dan daerah. Hubungan kewenangan ini merupakan hubungan yang berkaitan dengan tatanan sistem Rumah Tangga Daerah. Dimana hal tersebut akan mempengaruhi terhadap sejauh mana pemerintahan pusat maupun pemerintahan daerah memiliki wewenang untuk dapat menyelenggarakan dan melaksanakan setiap urusan-urusan pemerintahan. Dengan kata lain bahwa hubungan kewenangan ini akan menentukan bagaimana ruang lingkup urusan pemerintahan puat maupun daerah. Dasar dari adanya hubungan kewenangan ini adalah adanya penyerahan, pengakuan, ataupun adanya pembiaran dari suatu urusan sebagai urusan Rumah Tangga Daerah. Pembagian urusan tersebut meliputi urusan pemerintahan absolut yang sepenuhnya menjadi kewenangan pemerintahan pusat, kemudian urusan pemerintahan konkuren yang dibagi menjadi urusan pemerintahan pusat dan daerah dimana meliputi urusan pemerintahan wajib dan urusan pemerintahan pilihan yang disesuaikan dengan potensi yang dimiliki oleh suatu daerah, dan urusan pemerintahan umum yang menjadi kewenangan presiden sebagai kepala pemerintahan. ${ }^{12}$

\footnotetext{
10 Ni'matul Huda, 2014, Perkembangan Hukum Tata Negara Perdebatan dan Gagasan Penyempurnaan, Yogyakarta: FH UII Press, hlm. 411.

11 Bagir Manan, Opcit, hlm. 37.

12 Pasal 12 ayat (1) Undang-Undang Nomor 23 Tahun 2014 tentang Pemerintahan Daerah.
} 
Kosmik Hukum Vol. 20 No. 2 (2020): 73-80

E-ISSN: 2655-9242 | P-ISSN: 1411-9781

DOI: $10.30595 /$ kosmikhukum.v20i2.7156

Berkaitan dengan tatanan sistem Rumah Tangga Daerah, maka terdapat tiga sistem yakni pertama, sistem rumah tangga formil dimana dalam hal ini pembagian tugas dan kewenangan pusat dan daerah tidak dilakukan secara tegas dan rinci. ${ }^{13}$ Dalam sistem ini, daerah memiliki kebebasan untuk dapat mengatur serta menyelenggarakan urusan rumah tangganya. Kemudian sistem rumah tangga materil dimana urusan antara pemerintahan pusat dan daerah dibagi secara tegas dan lebih rinci. Ketiga, yani ajaran rumah tangga rill yang dalam UU Pemda 1974 disebut sebagai sistem sistem rumah tangga nyata. ${ }^{14}$ Sistem rumah tangga ini didasarkan kepada keadaan-keadaan yang nyata. Dalam sistem rumah tangga ini, daerah dapat mengatur dan mengurus urusan-urusan yang belum diatur dalam tingkat pusat maupun daerah di tingkat yang lebih tinggi.

Kedua, terdapat pula hubungan keuangan, yang merupakan hubungan untuk perimbangan keuangan antara pusat dengan daerah. Hubungan keuangan meliputi otonomi dan kecukupan pendapatan, otonomi dan pembelanjaan, dan keleluasaan untuk melakukan pinjaman, serta hubungan keuangan ini juga menggambarkan adanya desentralisasi dalam fiskal. Contohnya yaitu adanya Pendapatan Asli Daerah (PAD) yang didapatkan dari pajak misalnya Pajak Bumi dan Bangunan (PBB), retribusi daerah, dan hasil dari pemanfaatan Sumber Daya Alam melalui Badan Usaha Milik Daerah.

Ketiga, hubungan kelembagaan yang menunjukkan hubungan antar organisasi pusat dengan daerah. Hubungan tersebut terdiri dari external structure yang merupakan hubungan antar badan pemerintahan pusat, provinsi, serta kabupaten atau kota, dan internal structure yang merupakan hubungan antar kelengkapan atau organ pemerintahan daerah. Hubungan kelembagaan dapat ini meliputi hubungan antar jabatan dan hubungan antar pejabat. Adanya hubungan kelembagaan antara pusat dan daerah ini memberikan dampak dimana mengharuskan adanya kehati-hatian mengenai besaran kelembagaan yang diperlukan untuk melaksanakan tugas-tugas yang menjadi urusan masing-masing baik itu pusat, maupun daerah. ${ }^{15}$

Keempat, hubungan pengawasan merupakan konsekuensi yang muncul dari pemberian kewenangan kepada pemerintahan pusat maupun pemerintaan daerah. ${ }^{16}$ Hubungan pengawasan bertujuan untuk menjamin dan memastikan bahwa setiap pelaksanaan dari hubungan kewenangan, hubungan keyangan, dan hubungan kelembagaan antara pemerintahan pusat denga daerah terlaksana sesuai dengan ketentuan dalam perundangundangan.

Berdasarkan penjelasan diatas, maka dapat diketahui bahwa didalam desentralisasi terdapat beberapa hal yang dapat dijadikan tolok ukur hubungan pusat dan daerah yaitu hubungan yang terjadi antara pusat dan daerah harus tetap dapat mengakomodir dan mendukung hak-hak rakyat untuk turut serta didalam dalam penyelenggaraan pemerintahan daerah, dan hubungan antara pusat dan daerah tersebut haruslah sesuai dengan keadaan serta potensi masing-masing daerah yang kemudian diselenggarakan demi mewujudkan keadilan dan kesejahteraan daerah. ${ }^{17}$

\section{Hubungan Kewenangan Pusat dan Daerah dalam Penyelenggaraan Otonomi Daerah di Bidang Pendidikan Berdasarkan Undang-Undang Nomor 23 Tahun 2014 tentang Pemerintahan Daerah}

Otonomi daerah merupakan kewenangan suatu daerah otonom untuk dapat mengatur dan mengurus kepentingan masyarakat setempat menurut kebijakan sendiri yang pelaksanaan

13 Otong Rosadi, 2015, "Konstusionalitas Pengaturan Pemerintahan Daerah di Indonesia: Suatu Eksperimen yang Tidak Kunjung Selesai", Padjadjaran Jurnal Ilmu Hukum, Volume 2, Nomor 3, hlm. 545.

14 Tjahya Supriatna, 1999, Sistem Administrasi Pemerintahan Daerah di Indonesia, Jakarta: Rineka Cipta, hlm. 5.

15 Dewan Perwakilan Daerah, 2009, Kerangka Acuan Penelian Studi Hubungan Pusat Dan Daerah Kerjasama DPD RI Dengan Perguruan Tinggi Di Daerah, Jakarta: Dewan Perwakilan Daerah Republik Indonesia, hlm. 6.

16 Ibid

17 Yusdianto, 2015, “Hubungan Kewenangan Pusat dan Daerah Menurut Undang-Undang Nomor 23 Tahun 2014 tentang Pemerintahan Daerah", Padjadjaran Jurnal Ilmu Hukum, Volume 2, Nomor 3, hlm. 498. 
dan penyelenggaraannya sesuai dengan peraturan perundang-undangan. Otonomi daerah menjadi sangat penting, karena merupakan wujud dari desentralisasi, dimana terdapat sebuah tuntutan bahwa tujuan suatu negara secara keseluruhan harus dapat tercapai walaupun keseluruhan urusan tersebut tidak diselenggarakan oleh pemerintahan pusat secara langsung. ${ }^{18}$ Otonomi daerah merupakan wadah untuk berkembangnya penyelenggaraan pendidikan di daerah. ${ }^{19}$

Berkaitan dengan hal tersebut, bidang pendidikan termasuk didalam urusan pemerintahan yang konkuren. Hal tersebut berarti bahwa, kewenangan mengenai urusan di bidang pendidikan dibagi antara kewenangan pemerintahan pusat dengan pemerintahan daerah, adanya ketentuan tersebut tentunya harus diselenggarakan dan dilaksanakan sesuai dengan prinsip akuntabilitas, efisiensi, serta kepentingan nasional. Dalam hal ini, bidang pendidikan termasuk kedalam salah satu urusan pemerintahan yang wajib diselenggarakan oleh pemerintahan daerah, ${ }^{20}$ yang kemudian diperjelas didalam lampiran pembagian urusan tentang Pembagian Urusan Pemerintahan Bidang Pendidikan.

Adanya hubungan kewenangan antara pusat dengan daerah yang dalam hal ini berupa pembagian urusan dalam bidang pendidikan, tentunya memiliki tujuan yang diantaranya yaitu ${ }^{21}$ peningkatan mutu pendidikan di daerah melalui pengelolaan kearifan lokal, serta penyelenggaraan pendidikan yang diharapkan dapat terselenggara secara merata hingga ke pelosok daerah. Mengenai hubungan kewenangan antara pusat dan daerah dalam bidang pendidikan berdasarkan UU Pemda 2014, maka dapat dilihat dari beberapa hal yakni dalam hal manajemen pendidikan, kurikulum, akreditasi, pendidik dan tenaga kependidikan, perizinan pendidikan, serta dalam hal bahasa dan sastra.

Pertama, manajemen pendidikan, dalam hal ini pemerintah pusat memiliki kewenangan dalam hal menetapkan standar pendidikan secara nasional yang meliputi seluruh wilayah di Indonesia. Adanya penetapan tersebut tentu dimaksudkan agar setiap daerah yang ada di Indonesia memiliki standar pendidikan yang sama, sehingga kemudian diharapkan tidak ada wilayah yang memiliki standar pendidikan yang lebih tinggi ataupun yang lebih rendah. Selain itu, mengenai manajemen pendidikan tinggi juga menjadi kewenangan dari pemerintah pusat, dimana diketahui bahwa pendidikan tinggi yang merupakan bagian dari sistem pendidikan nasional memiliki peran yang penting dalam mencerdaskan bangsa Indonesia mengingat pula bahwa saat ini telah memasuki era globaisasi, maka diperlukan pendidikan tinggi yang mampu menghasilkan Sumber Daya Manusia Indonesia yang berkualitas agar dapat bersaing di dunia Internasional. ${ }^{22}$ Untuk mendukung hal tersebut, maka diperlukan adanya hubungan antara pemerintahan pusat dengan pemerintahan di daerah, dimana dalam penyelenggaraannya daerah provinsi memiliki kewenangan untuk melakukan pengelolaan terhadap pendidikan menengah. Berkaitan dengan hal tersebut, diketahui bahwa telah terjadi perubahan dimana di dalam UU Pemda 2004 pengelolaan pendidikan menengah dikelola oleh pemerintahan derah kabupaten atau kota, namun saat ini berdasarkan dengan UU Pemda 2014, pengelolaan pendidikan menengah tersebut menjadi kewenangan dari pemerintahan daerah provinsi. Menurut penulis, adanya peralihan kewenangan dari pemerintahan daerah kabupaten atau kota ke pemerintahan daerah provinsi adalah agar pengelolaan pendidikan menengah di daerah dapat melahirkan kebijakan pengelolaan pendidikan menengah yang seragam serta dapat terselenggara dengan lebih efektif dan efisien. Selain hal tersebut, pemerintahan daerah provinsi juga memiliki kewenangan dalam mengelola pendidikan khusus dimana merupakan pendidikan yang dilakukan terhadap peserta didik yang memiliki kelainan fisik maupun psikis

18 Mark Bray, 1991, "Centralization Versus Decentralization in Educational Administration: Regional Issues", Sage Journals, Volume 5, Issue 4.

19 H.A.R. Tilaar, 2003, Kekuasaan dan Pendidikan, Magelang: Indonesia Tera, hlm. 26.

20 Pasal 12 ayat (1) Undang-Undang Nomor 23 Tahun 2014 tentang Pemerintahan Daerah.

21 Yolanda Viesivica Daizy, 2015, "Pelaksanaan Penempatan Jabatan Kepala Sekolah Menengah Atas Negeri Di Kabupaten Pesawaran (Studi Pada Dinas Pendidikan Dan Kebudayaan Kabupaten Pesawaran)", Skripsi, Fakultas Hukum Universitas Lampung, hlm. 13.

22 Undang-Undang Nomor 12 Tahun 2012 tentang Pendidikan Tinggi. 
Kosmik Hukum Vol. 20 No. 2 (2020): 73-80

E-ISSN: 2655-9242 | P-ISSN: 1411-9781

DOI: $10.30595 /$ kosmikhukum.v20i2.7156

atau memiliki potensi kecerdasan dan bakat yang istimewa. ${ }^{23}$ Sedangkan daerah kabupaten atau kota diberikan kewenangan atas pengelolaan terhadap pendidikan dasar, Pendidikan Anak Usia Dini (PAUD), dan pendidikan nonformal yang berada di masing-masing daerah. Pendidikan formal dapat berupa pelatihan dan kursus yang menjadi penunjang pendidikan formal.

Berkaitan dengan penjelasan tersebut, terdapat negara-negara di Asia Tenggara yang juga sepaham, dimana Singapura melakukan desentralisasi pendidikan dengan harapan setiap lembaga pendidikan yang ada menjadi otonom sehingga dapat menjadi lembaga yang lebih inovatif, kemudian terdapat Timor-Leste yang menginginkan penyelenggaraan pendidikan lebih transparan, dan Vietnam memandang karena pendidikan merupakan investasi untuk masa depan maka penting untuk membuat manajemen layanan pendidikan menjadi lebih efisien dan efektif untuk menghasilkan lebih baik. ${ }^{24}$

Kedua, kurikulum. Dalam hal ini pemerintahan pusat memiliki kewenangan untuk menetapkan kurikulum pendidikan secara nasional yang meliputi kurikulum pendidikan menengah, dasar, PAUD, dan nonformal. ${ }^{25}$ Misalnya, dalam hal ini diketahui bahwa saat ini sistem pendidikan nasional menggunakan kurikulum 2013 untuk pendidikan formal. Adanya penetapan kurikulum yang menjadi kewenangan pusat adalah bertujuan agar penyelenggaraan pendidikan yang berlangsung di setiap daerah dapat berjalan secara merata dan seragam dengan berdasarkan kepada kurikulum yang telah ditetapkan. Untuk melengkapi hal tersebut, maka pemerintahan daerah provinsi diberikan kewenangan dalam hal menetapkan kurikulum muatan lokal pendidikan menengah dan pendidikan khusus. Sedangkan daerah kabupaten atau kota diberikan kewenangan untuk menetapkan kurikulim muatan lokal pendidikan dasar, PAUD, dan nonformal. Kurikulum muatan lokal yang dimaksudkan dalam hal ini yaitu program pendidikan yang dirancang oleh Dinas Pendidikan daerah untuk dilaksanakan dalam proses belajar mengajar kepada peserta didik mengenai kebudayaan daerah setempat.

Ketiga, akreditasi. Hal ini berkaitan dengan penetapan standar pendidikan secara nasional yang dilakukan oleh pemerintah pusat. Dimana akreditasi yang dilakukan terhadap setiap lembaga pendidikan oleh pemerintah pusat, merupakan dasar dari penetapan standar pendidikan secara nasional. Hal tersebut meliputi penilaian terhadap kelayakan dari suatu lembaga pendidikan yang telah didasarkan dengan kriteria yang telah ditetapkan. Dalam hal ini, yang memiliki kewenangan untuk melakukan akreditasi adalah pemerintahan pusat. Hal tersebut, dilakukan oleh pemerintah pusat supaya terdapat keseragaman terhadap indikator penilaian kelayakan suatu lembaga pendidikan.

Keempat, pemerintahan pusat memiliki kewenangan untuk melakukan pengendalian terhadap tenaga kependidikan yang merupakan Pegawai Negeri Sipil, lintas Daerah provinsi yang meliputi pemindahan dan pengubahan formasi. Dalam hal ini, berbeda dengan kewenangan pemerintahan pusat, maka pemerintahan daerah provinsi memiliki kewenangan untuk melakukan pemindahan tenaga kependidikan lintas daerah kabupaten atau kota yang berada dalam satu daerah provinsi. Serta, kewenangan pemerintah daerah kabupaten atau kota dalam hal ini adalah Pemindahan pendidik dan tenaga kependidikan dalam Daerah kabupaten atau kota.

Kelima yaitu hal perizinan pendidikan. Mengingat bahwa pengelolaan pendidikan tinggi merupakan vkewenangan pemerintahan pusat, maka yang memiliki wewenang untuk melakukan penerbitan izin perguruan tinggi swasta juga dimiliki oleh pemerintahan pusat, selain itu dalam pemerintahan pusat juga berkewenangan dalam penerbitan izin penyelenggaraan satuan pendidikan asing, dalam urusan pemerintahan yang konkuren, akan menjadi kewenangan pemerintahan pusat apabila berhubungan dengan lintas negara. Agar birokrasi dapat berjalan dengan lebih efekif dan efisien, maka dalam hal penerbitan izin

23 Pasal 32 (1) Undang-Undang Nomor 20 Tahun 2003 tentang Sistem Pendidikan Nasional.

24 Regional Center for Educational Innovation and Technology, 2012, Decentralization of Educational Management in Southeast Asia, Philippine: Seameo Innotech, hlm. 56.

25 Undang-Undang Nomor 23 Tahun 2014 tentang Pemerintahan Daerah 
terhadap pendidikan khusus dan pendidikan menengah menjadi kewenangan pemerintahan daerah provinsi, mengingat pula kewenangan pengelolaannya berada pada pemerintahan daerah provinsi. Demikian pula dengan pemerintahan daerah kabupaten atau kota memiliki wewenang untuk melakukan penerbitan izin pendidikan dasar, PAUD, dan nonformal yang diselenggarakan oleh masyarakat. Keenam, bahasa dan sastra. Pemerintah pusat memiliki kewenangan untuk melakukan pembinaan terhadap bahasa indonesia. Hal tersebut dilakukan oleh pusat sebab bahasa Indonesia merupakan bahasa nasional sebagai bahasa persatuan seluruh rakyat Indonesia, sehingga pusat memiliki kewajiban untuk dapat mempertahankan serta melestarikan bahasa Indonesia, melalui pembinaan dan penerapannya didalam proses belajar dan mengajar yang dilaksanakan oleh setiap lembaga pendidikan, contoh hal nyata yaitu adanya mata pelajaran Bahasa Indonesia pada setiap jenjang pendidikan. Berkaitan dengan hal tersebut, maka penting pula untuk mempertahankan kearifan lokal daerah setempat, salah satunya yaitu dengan ,melestarikan bahasa san sastra daerah setempat yang dilakukan dengan pendidikan bahasa daerah. Adanya hal tersebut dapat dijadikan salah satu muatan dalam kukikulum muatan lokal. Dalam hal ini, pemerintah daerah provinsi memiliki kewajiban untuk melakukan pembinaan tersebut dalam hal penuturnya lintas daerah kabupaten atau kota dalam satu daerah provinsi, serta kewenangan yang dimiliki oleh daerah kabupaten atau kota yakni menyelenggarakan pembinaan dalam hal penuturnya berada didalam satu daerah kabupaten atau kota.

Melalui penjelasan diatas, maka dapat dikatakan bahwa adanya hubungan kewenangan antara pemerintahan pusat dengan daerah, baik itu daerah provinsi maupun daerah kabupaten atau kota adalah sebagai suatu cara yang efisien dan efektif untuk menciptakan layanan pendidikan yang berkualitas secara merata di seluruh daerah di Indonesia. ${ }^{26}$

\section{Penutup}

Mengingat bahwa Indonesia adalah negara Kesatuan, maka Otonomi daerah dapat dikatakan sebagai sebuah instrument untuk memelihara negara kesatuan untuk mewujudkan pemerataan kemakmuran, kesejahteraan, dan keadilan di berbagai bidang, salah satunya pendidikan. Adanya otonomi daerah melahirkan hubungan antara pemerintahan pusat dengan daerah, dimana salah satunya yaitu hubungan kewenangan yang dalam hal ini adalah hubungan kewenangan di bidang pendidikan. Mengingat bahwa sistem pendidikan nasional memiliki peran yang penting dalam mencerdaskan bangsa Indonesia mengingat pula bahwa saat ini telah memasuki era globaisasi, maka diperlukan pendidikan yang mampu menghasilkan Sumber Daya Manusia Indonesia yang berkualitas agar dapat bersaing di dunia Internasional.

Mengenai hubungan kewenangan antara pusat dan daerah dalam bidang pendidikan berdasarkan UU Pemda 2014, maka dapat dilihat dari beberapa hal yakni dalam hal manajemen pendidikan, kurikulum, akreditasi, pendidik dan tenaga kependidikan, perizinan pendidikan, serta dalam hal bahasa dan sastra. Adanya pembagian urusan tersebut merupakan urusan pemerintahan konkuren telah menggambarkan wujud dari otonomi daerah sebagai wujud dari desentralisasi di Indonesia. Dengan demikian, adanya hubungan kewenangan antara pemerintahan pusat dengan daerah tentunya dengan tujuan untuk lebih mendekatkan pelayanan pendidikan kepada masyarakat di setiap daerah di Indonesia serta efektivitas dalam penyelenggaraan dan pelaksanaan kebijakan pendidikan.

\section{Daftar Pustaka}

Akbal, Muhammad, 2016, "Harmonisasi Kewenangan Antara Pemerintah Pusat dan Daerah Dalam Penyelenggaraan Otonomi Daerah", Jurnal Supremasi, Volume XI, Nomor 2. 26 UNESCO, “Decentralization in Education: National Policies and Practices", Education Policies and Strategies, 2005,
http:/ / unesdoc.unesco.org/images/0014/001412/141221e.pdf, diakses 25 November 2018. 
Kosmik Hukum Vol. 20 No. 2 (2020): 73-80

E-ISSN: 2655-9242 | P-ISSN: 1411-9781

DOI: $10.30595 /$ kosmikhukum.v20i2.7156

Asshiddiqie, Jimly, 2013, Komentar atas Undang-Undang Dasar Negara Republik Indonesia Tahun 1945, Sinar Grafika, Jakarta.

Bray, Mark, 1991, "Centralization Versus Decentralization in Educational Administration: Regional Issues", Sage Journals, Volume 5, Issue 4.

Daizy, Yolanda Viesivica, 2015, "Pelaksanaan Penempatan Jabatan Kepala Sekolah Menengah Atas Negeri Di Kabupaten Pesawaran (Studi Pada Dinas Pendidikan Dan Kebudayaan Kabupaten Pesawaran)", Skripsi, Fakultas Hukum Universitas Lampung, 2015.

Dewan Perwakilan Daerah, 2009, Kerangka Acuan Penelian Studi Hubungan Pusat Dan Daerah Kerjasama DPD RI Dengan Perguruan Tinggi Di Daerah, Dewan Perwakilan Daerah Republik Indonesia, Jakarta.

Fiske, Edward B., 1996, Decentralization of Education: Politics and Consensus, The World Bank, Washington DC.

Huda, Ni'matul, 2014, Perkembangan Hukum Tata Negara Perdebatan dan Gagasan Penyempurnaan, FH UII Press, Yogyakarta.

Lauglo, J, 1999, "Forms of Decentralisation and Their Implications for Education", Comparative Education, Volume 31, Issue 1.

Manan, Bagir , 1990, "Hubungan Antara Pusat Dan Daerah Menurut Asas Desentralisasi Berdasarkan UUD 1945", Disertasi, Fakultas Hukum Universitas Padjadjaran Bandung.

Manan, Bagir, 2001, Menyongsong Fajar Otonomi Daerah, PSH FH UII, Yogyakarta.

Mawardi, Oentarto Sindung, 2004, Menggagas Format Otonomi Daerah Masa Depan, Samitra Media Utama, Jakarta.

Parry, Terry Rounds, 2008, "Decentralization and Privatization: Education Policy in Chile", Journal of Public Policy, Volume 17, Issue 1.

Regional Center for Educational Innovation and Technology, 2012, Decentralization of Educational Management in Southeast Asia, Seameo Innotech, Philippine.

Rosadi, Otong, 2015, “Konstusionalitas Pengaturan Pemerintahan Daerah di Indonesia: Suatu Eksperimen yang Tidak Kunjung Selesai", Padjadjaran Jurnal Ilmu Hukum, Volume 2, Nomor 3.

Supriatna, Tjahya, Sistem Administrasi Pemerintahan Daerah di Indonesia, Rineka Cipta, Jakarta, 1999.

Tilaar, H.A.R., 2003, Kekuasaan dan Pendidikan, Indonesia Tera, Magelang.

UNESCO, 2005, "Decentralization in Education: National Policies and Practices", Education Policies and Strategies, diakses dari http:// unesdoc.unesco.org/images/0014/001412/141221e.pdf, pada 20 Maret 2020.

Wijayanti, Septi Nur, 2016, "Hubungan Antara Pusat dan Daerah Dalam Negara Kesatuan Republik Indonesia Berdasarkan Undang-Undang Nomor 23 Tahun 2014", Jurnal Media Hukum, Volume 23, Nomor 2.

Yusdianto, "Hubungan Kewenangan Pusat dan Daerah Menurut Undang-Undang Nomor 23 Tahun 2014 tentang Pemerintahan Daerah", Padjadjaran Jurnal Ilmu Hukum, Volume 2, Nomor 3, 2015. 